\title{
Quality of life predictors for people living with HIV/AIDS in an impoverished region of Brazil
}

\author{
Antônio Carlos Ferreira[1],[2], Antônio Lúcio Teixeira ${ }^{[1],[3],}$ \\ Marise Fagundes Silveira ${ }^{[4]}$ and Mariângela Carneiro ${ }^{[1],[5]}$
}

\author{
[1]. Programa de Pós-Graduação em Ciências da Saúde: Infectologia e Medicina Tropical, Faculdade de Medicina, \\ Universidade Federal de Minas Gerais, Belo Horizonte, MG, Brasil. \\ [2]. Departamento de Saúde Mental e Saúde Coletiva, Universidade Estadual de Montes Claros, Montes Claros, MG, Brasil. \\ [3]. Departamento de Clínica Médica, Faculdade de Medicina, Universidade Federal de Minas Gerais, Belo Horizonte, MG, Brasil. \\ [4]. Departamento de Ciências Exatas, Universidade Estadual de Montes Claros, Montes Claros, MG, Brasil. \\ [5]. Departamento de Parasitologia, Instituto de Ciências Biológicas, Universidade Federal de Minas Gerais, Belo Horizonte, MG, Brasil.
}

\begin{abstract}
Introduction: Quality of life (QoL) is important for people living with HIV/AIDS, particularly as the disease progresses. This study evaluated the QoL of people living with HIV/AIDS (PLWHA), as well as its predictors, in one of the most impoverished regions of Brazil. Methods: This cross-sectional study was conducted with patients older than 18 years with HIV/AIDS from two specialized HIV/AIDS care centers in the city of Montes Claros between 2013 and 2014. Sample size was calculated considering the estimates of mean scores for various dimensions of the European Portuguese version of the World Health's Organization Quality of Life Instrument in HIV Infection (WHOQOL-HIV Bref). The following parameters were adopted: CI of $95 \%$, estimated mean scores for QoL equal to 15, estimated variance for QoL scores equal to 16 , and $5 \%$ relative margin of error. An increase of $20 \%$ was established to compensate for possible non-responses or losses, and correcting any design effect, adopting a deff equal to 2.0. Calculations revealed the need to interview at least 221 patients. Therefore, 226 patients living with HIV/AIDS were randomly selected. Results: A total of 226 patients with mean age 43.7 years were evaluated: $51.8 \%$ men, $51.8 \%$ unemployed, $51.8 \%$ with low schooling level, $89.8 \%$ used antiretrovirals, and $43.3 \%$ experienced depression. Despite this, data indicated that $65 \%$ self-assessed their QoL as good and very good. Low QoL was associated with sociodemographic variables and some clinical variables. Conclusions: Depression was the main predictor of low QoL in all domains evaluated.
\end{abstract}

Keywords: quality of life. HIV. Acquired immune deficiency syndrome. Depression. WHOQOL-HIV Bref.

\section{INTRODUCTION}

Data obtained by the Brazilian Ministry of Health in 2014 revealed that 734,000 people were living with HIV/AIDS, corresponding to a prevalence of $0.4 \%$ in the country ${ }^{1}$. Since 1996 , the Brazilian government has been granting universal access to antiretroviral therapy (ART), thereby increasing the survival rates of HIV/AIDS patients and reducing hospitalizations ${ }^{2}$. In light of this treatment reality, which has progressively added therapies with improved efficacy, it becomes essential to investigate the quality of life (QoL) of people living with HIV/AIDS (PLWHA), especially given the long timeframe of the disease and the stigma still associated with it ${ }^{3,4}$.

Currently, there is no approach broad enough to embrace the concept of QoL. According to the World Health Organization,

Corresponding author: Dr. Antônio Carlos Ferreira.

e-mail: acf452000@yahoo.com.br

Received 5 December 2017

Accepted 31 August 2018
QoL is defined as "the individual's perception of his/her position in life in the context of the culture and value system in which he/ she lives and in relation to his/her goals, expectations, standards and concerns" $", 6$. Indeed, the World Health Organization Quality of Life Assessment (WHOQOL) is widely used to evaluate QoL because it allows the assessment of this concept according to six domains: physical, psychological, independence level, social relations, environment, and spirituality/religiosity ${ }^{6}$.

Up to now, few studies have analyzed the QoL of PLWHA in Brazil using the WHOQOL and all revealed an intermediate level in all domains ${ }^{3,7,8,9}$. However, these studies did not take into account the highly heterogeneous characteristics of the country and its various geographic regions, which exhibit considerable social, cultural, and economic differences. Certainly, patients analyzed in these studies lived in affluent parts of the country such as the state of São Paulo and the southern region of Brazil. However, some of the poorest municipalities presenting low human development index (HDI) in Brazil are located in the north and northeast of the state of Minas Gerais and the question about the QoL of PLWHA in these areas has remained unanswered. 
To fill this knowledge gap, we evaluated the QoL and identified its predictors using the WHOQoL-HIV Bref, MiniMental State Examination (MMSE), Cut-down, Annoyed, Guilty, and Eye opened (CAGE) questionnaire, and Beck Depression Inventory (BDI), as well as clinic and sociodemographic information obtained from PLWHA residing in Montes Claros, which is a health care reference city for all the northern region of Minas Gerais. Health facilities at this town cover some of the poorest areas in Brazil, such as the Jequitinhonha and Mucuri Valleys and the south of the state of Bahia.

\section{METHODS}

\section{Study design and population}

This cross-sectional study was conducted with patients older than 18 years with HIV/AIDS from two specialized HIV/ AIDS care centers between 2013 and 2014. These centers are established in the city of Montes Claros.

Calculation of the sample size was performed considering the estimates of mean scores for the various dimensions of the WHOQOL-HIV Bref ${ }^{5}$. The following parameters were adopted: CI of $95 \%$, estimated mean scores for QoL equal to 15, estimated variance for QOL scores equal to 16 , and a $5 \%$ relative margin of error. An increase of $20 \%$ was established to compensate for possible non-responses or losses and to correct any design effect, adopting a deff equal to 2.0. Calculations revealed the need to interview at least 221 patients $^{10}$. Therefore, 226 patients living with HIV/AIDS were randomly selected for the study.

The research was submitted to the Ethics Committee of the Universidade Federal de Minas Gerais (UFMG) and approved under number CAAE-UFMG-11323113.8.0000.5149. Patients were included in the study after signing the informed consent.

\section{Interviews and instruments}

Interviews were conducted by previously trained interviewers. WHOQOL-HIV Bref was used as an assessment instrument to gather QoL data ${ }^{5,11,12,13}$. WHOQOL-HIV Bref is a 29-item questionnaire that measures six QoL domains: physical, psychological, independence level, social relations, environment, and spirituality. It also contains two questions that examine self-perception of overall QoL and health (Table 1). Items are evaluated in a 5-point Likert scale, where 1 indicates low and negative perceptions and 5 indicates high and positive perceptions. QoL scores were calculated according to the WHO standardized algorithm, on a scale from 4 to 20, with higher scores indicating $\mathrm{QoL}^{6}$. On the other hand, MMSE assessed the cognitive functions of PLWHA, BDI detected symptoms of depression, and CAGE examined alcohol consumption.

Socio-economic, demographic, and clinical data were obtained using standardized questionnaires. Socio-demographic data included gender, age, ethnicity, marital status, level of education, profession, employment, and socioeconomic level. The socio-economic level was evaluated based on the Brazilian

Economic Classification Criterion devised by the Brazilian Association of Research Companies ${ }^{14}$.

Clinical and laboratory data were collected by interviews and medical records informing about complaints related to the week before the interviews, diseases prior to HIV, conditions related to HIV (use of ART and time of diagnosis), plasma viral load, and $\mathrm{CD}^{+}$T-lymphocyte count (last exam before the interviews).

\section{Statistical analysis}

Absolute and relative frequencies were used to describe patients' sociodemographic and clinical-epidemiological characteristics. These characteristics were considered as independent variables.

The QoL variable and its domains were analyzed as continuous variables, and scores were compared with the sociodemographic and clinical-epidemiological characteristics. For this purpose, we used the non-parametric Mann-Whitney U test (to compare two groups) and Kruskal-Wallis test (to compare more than two groups). The QoL variable did not present normal distribution according to the KolmogorovSmirnov and Shapiro-Wilk tests.

To calculate the scores of each QoL domain, which ranged from 4 to 20 , we used the equation suggested by the $\mathrm{WHO}^{6}$. Data were described as means, medians, standard deviations, minimum and maximum values, and tertiles. QoL domains were categorized and patients were classified into two groups according to QoL scores, considering the tertiles of the sample. Patients with scores in the first and second tertiles were placed in the first group (lower scores), and patients with scores in the third tertile were placed in the second group (higher scores). The QoL categorized in these two groups was considered as the dependent variable (outcome).

To identify the independent variables associated with QoL domains, we used logistic regression models and adjusted odds ratio estimates with their respective $95 \%$ confidence intervals (CIs). Initially, bivariate analyses were performed through the Chi-square test and variables that demonstrated a descriptive level $p<0.20$ in this stage were selected for multiple analyses.

A stepwise forward procedure was adopted for the multiple regression model. Variables that demonstrated a significant association with the outcome, at the level of $\mathrm{p}<0.05$, remained in the final model. To evaluate the goodness-of-fit quality of the multiple models the Hosmer-Lemeshow and Pseudo- $\mathrm{R}^{2}$ tests were used.

Data were entered in the EpiData software, version 3.1, and analysis was conducted by the Statistical Package for the Social Sciences (SPSS), version 18.0.

\section{RESULTS}

Out of 226 PLWHA recruited, 117 (51.8\%) were male. Patients' age was between 19 and 72 years, with most of them $(63.8 \%)$ being over 40 years, and a median of 43.7 years $(25 \%$ and $75 \%$ of patients were 35 and 51 years, respectively). Regarding income, $56.3 \%$ of patients living with HIV/AIDS earned less than one Brazilian minimum wage (approximately US\$ 310.00 in 2014), with most of them (92.1\%) being categorized in the socioeconomic levels $\mathrm{C}$ and $\mathrm{D}$. Most of these patients $(51.8 \%)$ had a low education level, having only four years of total schooling (Table 2).

Clinical complaints reported included headache, joint pain, cough, and dyspnea. Main diseases mentioned prior 
TABLE 1: WHOQoL-HIV Bref: domains and items.

\begin{tabular}{|c|c|}
\hline Domains & Items \\
\hline I - Physical & $\begin{array}{l}\text { 3. To what extent do you feel that (physical) pain prevents you from doing what you need to do? } \\
\text { 14. Do you have enough energy in your day-to-day life? } \\
\text { 21. How satisfied are you with your sleep? } \\
\text { 4. How bothered are you with having (or having had) an unpleasant physical problem related to your HIV infection? }\end{array}$ \\
\hline II - Psychological & $\begin{array}{l}\text { 6. How much do you enjoy life? } \\
\text { 11. How well are you able to concentrate? } \\
\text { 15. Are you able to accept your bodily appearance? } \\
\text { 24. How satisfied are you with yourself? } \\
\text { 31. How often do you have negative feelings such as bad mood, despair, anxiety or depression? }\end{array}$ \\
\hline III - Independence level & $\begin{array}{l}\text { 5. How much do you need any medical treatment in your daily life? } \\
\text { 20. How well are you able to get around? } \\
\text { 22. How satisfied are you with your ability to perform your day-to-day activities? } \\
\text { 23. How satisfied are you with your capacity to work? }\end{array}$ \\
\hline
\end{tabular}

\begin{tabular}{|c|c|}
\hline IV - Social relations & $\begin{array}{l}\text { 17. To what extent do you feel accepted by people you know? } \\
\text { 25. How satisfied are you with your personal relationships (friends, relatives, colleagues, acquaintances)? } \\
\text { 26. How satisfied are you with your sex life? } \\
\text { 27. How satisfied are you with the support you get from your friends? }\end{array}$ \\
\hline $\begin{array}{l}\text { Domain V - } \\
\text { Environment }\end{array}$ & $\begin{array}{l}\text { 12. How safe do you feel in your daily life? } \\
\text { 13. How healthy is your physical environment (climate, noise, pollution, attractions)? } \\
\text { 16. Do you have enough money to meet your needs? } \\
\text { 18. How available is the information that you need in your day-to-day life? } \\
\text { 19. To what extent do you have the opportunity for leisure activities? } \\
\text { 28. How satisfied are you with the conditions of your living place? } \\
\text { 29. How satisfied are with your access to health services? } \\
\text { 30. How satisfied are you with your mode of transportation? }\end{array}$ \\
\hline VI - Spirituality & $\begin{array}{l}\text { 7. To what extent do you feel your life is meaningful? } \\
\text { 8. Are you bothered by the fact that people blame you for your HIV status? } \\
\text { 9. How much do you fear the future? } \\
\text { 10. How much do you worry about death? }\end{array}$ \\
\hline $\begin{array}{l}\text { Self-perception of } \\
\text { overall quality of life } \\
\text { and health }\end{array}$ & $\begin{array}{l}\text { 1. How would you rate your quality of life? } \\
\text { 2. How satisfied are you with your health? }\end{array}$ \\
\hline
\end{tabular}

Source: Adapted from WHOQoL-HIV group, 2002.

WHO, 2002. World Health Organization [2002]. Scoring and Coding for the WHOQoL-HIV Instruments Mental Health: Evidence and Research Department of Mental Health and Substance Dependence World Health Organization Geneva. 
TABLE 2: Socio-demographic characteristics.

\begin{tabular}{|c|c|c|}
\hline Socio-demographic characteristics & $\mathbf{n}$ & $\%$ \\
\hline \multicolumn{3}{|l|}{ Gender } \\
\hline Male & 117 & 51.8 \\
\hline \multicolumn{3}{|l|}{ Completed age in years } \\
\hline 19 to 29 & 21 & 9.3 \\
\hline 40 to 49 & 72 & 31.9 \\
\hline 50 to 59 & 56 & 24.7 \\
\hline 60 or more & 16 & 7.1 \\
\hline \multicolumn{3}{|l|}{ Ethnicity* } \\
\hline pardo & 158 & 70.5 \\
\hline \multicolumn{3}{|l|}{ Marital status } \\
\hline married/stable union & 87 & 38.6 \\
\hline single & 81 & 35.8 \\
\hline divorced/separated & 34 & 15.0 \\
\hline widow/widower & 24 & 10.6 \\
\hline \multicolumn{3}{|l|}{ Education } \\
\hline illiterate/ Incomplete primary school & 37 & 16.4 \\
\hline primary school (completed) & 80 & 35.4 \\
\hline elementary school (completed) & 37 & 16.4 \\
\hline up to 1 & 116 & 56.3 \\
\hline 1.1 to 2 & 43 & 20.8 \\
\hline 2.1 to 3 & 24 & 11.7 \\
\hline over 3 & 23 & 11.2 \\
\hline \multicolumn{3}{|l|}{ Socioeconomic level } \\
\hline A & 0 & 0.0 \\
\hline B & 18 & 8.0 \\
\hline $\mathrm{C}$ & 124 & 54.8 \\
\hline $\mathrm{D}$ & 84 & 37.2 \\
\hline
\end{tabular}

*Missing answers.

to the interview were: pneumonia, herpes, and tuberculosis. Most patients $(89.8 \%)$ were undergoing ART treatment, 55.8\% presented CD4 ${ }^{+}$T-lymphocyte counts over 500 cells $/ \mathrm{mm}^{3}$, and plasma viral load was undetectable in $65.0 \%$ of them. Symptoms of depression were present in $43.3 \%$ of the interviewees (Table 3).

Crude scores obtained with the WHOQOL-HIV Bref assessment instrument for each QoL domain. Data indicated that 65\% self-assessed their QoL as good and very good. Lower QoL scores were associated with higher levels of depression symptoms. In fact, the proportion of PLWHA with low QoL scores was higher among patients with depression than among those without these symptoms.

Table 4 shows the results of the multiple logistic regression models. The female gender was associated with lower QoL 
TABLE 3: Clinical-epidemiological characteristics.

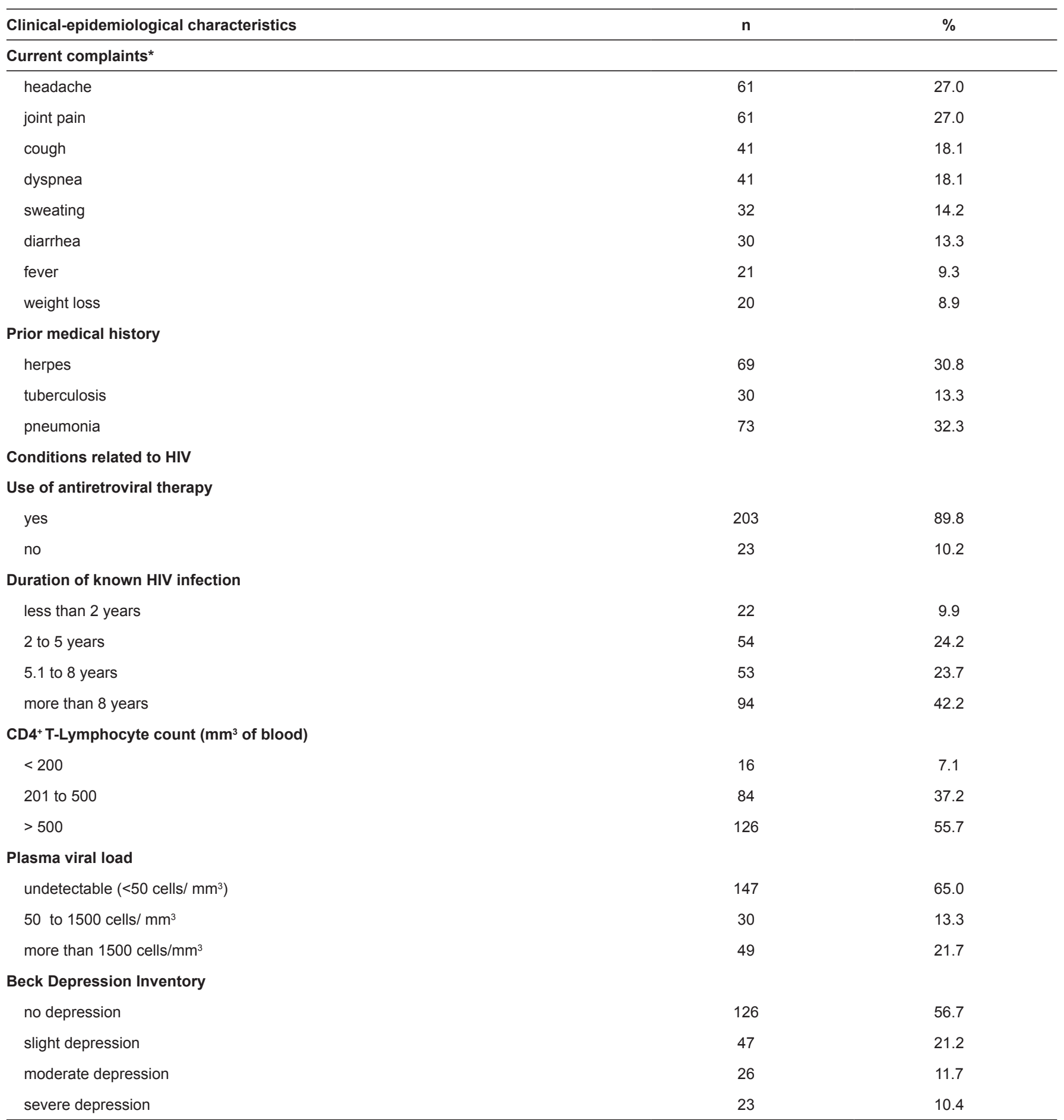

*There are individuals with two or more complications; therefore, the total is over $100 \%$.

scores in the psychological $(\mathrm{OR}=2.4)$ and spirituality $(\mathrm{OR}=2.1)$ domains. Being under 44 years was associated with worse overall QoL scores $(\mathrm{OR}=2.1)$. Being unemployed was associated with worse QoL scores in the physical $(\mathrm{OR}=2.1)$, psychological $(\mathrm{OR}=2.7)$, independence $(\mathrm{OR}=3.6)$, and environment $(\mathrm{OR}=1.9)$ domains. Having a very low income was associated with lower QoL scores in the social relations' domain $(\mathrm{OR}=1.8)$. Being part of the least privileged socioeconomic levels was associated with low QoL scores in the physical $(\mathrm{OR}=4.4)$, spirituality $(\mathrm{OR}=2.9)$, and overall $\mathrm{QoL}(\mathrm{OR}=2.7)$ domains (Table 4).

Among clinical complaints reported, sweating was associated with low QoL in the psychological $(\mathrm{OR}=3.9)$ and environment domains $(\mathrm{OR}=4.3)$; fever was associated with low QoL in the independence domain $(\mathrm{OR}=7.7)$; joint pain was 
associated with low QoL in the physical domain ( $\mathrm{OR}=3.1)$; finally, CD4 cells count $<500$ was associated with low QoL in the psychological domain $(\mathrm{OR}=2.2)$.

On the other hand, depression showed a significant association with lower QoL scores in all domains: physical $(\mathrm{OR}=11.3 ; \mathrm{p}<0.001)$, psychological $(\mathrm{OR}=12.4 ; \mathrm{p}=0.000)$, independence $(\mathrm{OR}=7.2$; $\mathrm{CI} 95 \%$ 3.58-14.64; $\mathrm{p}<0.001)$, social relations $(\mathrm{OR}=4.1 ; \mathrm{p}<0.001)$, environment $(\mathrm{OR}=5.7 ; \mathrm{p}<0.001)$, spirituality $(\mathrm{OR}=5.3 ; \mathrm{p}<0.001)$, and overall $\mathrm{QoL}(\mathrm{OR}=3.0$; $\mathrm{p}<0.001$ ) (Table 4).

\section{DISCUSSION}

This is the first study to assess QoL in combination with sociodemographic and clinical characteristics, including depression, among PLWHA residing in the north of Minas Gerais, one of the poorest regions of Brazil. The WHOQOL-HIV Bref assessment instrument revealed an intermediate level of QoL in all domains analyzed. The highest scores were obtained in the spirituality domain and the lowest in the environment domain. Worse QoL was associated with sociodemographic characteristics (being under 44, female, unemployed, having low income, and belonging to an underprivileged socioeconomic level) as well as with clinical variables (pneumonia, fever, sweating, joint pain, $C D 4 \leq 500$, and depression). The presence of depression symptoms was the main predictor of low QoL in all domains. Studies analyzing QoL of PLHA residing in other Brazilian regions have revealed similar intermediate levels of QoL in all the domains analyzed ${ }^{3,7,9}$. The similarity between our findings and those results reported by these studies is somewhat unexpected since patients analyzed herein lived in one of the poorest regions of the country according to HDI ${ }^{15}$.

In this study, being female was associated with low QoL in the psychological and spirituality domains. Similar results have been reported previously ${ }^{8,9,16}$. A study that assessed QoL of women with HIV/AIDS revealed that those with income of more than one minimum wage and holding a job had higher QoL scores in the psychological domain. Women with a high level of education had better QoL scores in the social relations' domain than those with lower levels of education or illiterate ${ }^{8}$. However, in this study, educational level was not associated with QoL, despite the fact that women had more than doubled the risk of low QoL in the two domains mentioned above.

The mean age in this study (43.7 years old) was higher than that reported in studies about QoL of PLWHA in Brazil. Indeed, the mean age of a study carried out in the southern State of Rio Grande do Sul was 40.9 years ${ }^{9}$. Studies conducted

TABLE 4: Odds ratio (OR) with respective 95\% confidence intervals for lower QoL scores evaluated using the WHOQoL-HIV Bref according to sociodemographic variables and clinical-epidemiological characteristics in people living with HIVIAIDS. Montes Claros, MG, Brazil, 2014.

\begin{tabular}{|c|c|c|c|c|c|c|c|}
\hline \multirow{2}{*}{ Variables } & \multicolumn{7}{|c|}{ WHOQoL-HIV Bref Quality of Life Domains } \\
\hline & \multicolumn{7}{|c|}{ OR (IC 95\%) } \\
\hline \multicolumn{8}{|l|}{$\begin{array}{l}\text { Socio-demographic } \\
\text { characteristics }\end{array}$} \\
\hline Sex - Male & $2.4(1.2-4.9)$ & & & & & $2.1(1.1-3.8)$ & \\
\hline Currently working & $2.1(1.2-4.1)$ & $2.7(1.3-5.6)$ & $3.7(1.8-7.1)$ & & $1.9(1.0-3.5)$ & & \\
\hline $\begin{array}{l}\text { Individual income }-U p \text { to } \\
1 \mathrm{BMW}^{*}\end{array}$ & & & & $1.8(1.0-3.5)$ & & & \\
\hline Socioeconomic level - D & $4.4(2.1-9.1)$ & & & & & $2.9(1.4-5.7)$ & $2.7(1.4-5.0)$ \\
\hline \multicolumn{8}{|l|}{$\begin{array}{l}\text { Clinical-epidemiological } \\
\text { characteristics }\end{array}$} \\
\hline Joint Pain & $3.1(1.3-7.1)$ & & & & & & \\
\hline Pneumonia & & & & & & & $2.4(1.2-4.6)$ \\
\hline CD4 count $<500$ & & $2.2(1.1-4.4)$ & & & & & \\
\hline Symptoms of depression & $11.3(5.4-23.8)$ & $12.4(5.6-27.8)$ & $7.2(3.6-14.6)$ & $4.1(2.2-7.6)$ & $5.7(2.8-11.8)$ & $5.3(2.7-10.6)$ & $3.0(2.7-9.3)$ \\
\hline \multicolumn{8}{|l|}{$\begin{array}{l}\text { Model adjustment } \\
\text { quality statistic }\end{array}$} \\
\hline Hosmer-Lemeshow & 0.690 & 0,996 & 0.523 & 0.793 & 0.321 & 0.582 & 0.290 \\
\hline Pseudo- $R^{2}$ & 0.456 & 0.461 & 0.437 & 0.169 & 0.270 & 0.274 & 0.323 \\
\hline
\end{tabular}

Ph: physical; Ps: psychological; IL: independence level; SR: social relations; En: environment; Sp: spirituality; QO: QoL-Overall. *BMW: Brazilian minimum wage. 
in São Paulo found mean ages of $39^{4}$ and 38.2 years old ${ }^{17}$. We found that PLWHA older than 44 had better QoL than younger PLWHA. This data contrasts to those reported by Ferreira and Paniago ${ }^{18}$ showing that younger PLWHA (20 to 39 years) had better mean scores for QoL, and is in agreement with Passos and Souza (2015) ${ }^{9}$, who revealed that PLWHA younger than 47 years had lower QoL in all domains, except in the independence level domain. Gaspar et al. (2011) reported that women over 50 years with low social and economic levels had lower QoL scores in the independence level domain.

The current study revealed that, although a low level of education predominated among PLWHA interviewed, this variable was not associated with QoL. Our results contrast with those presented in previous studies showing that low level of schooling was directly proportional to scores found in the physical, psychological, independence level, and overall QoL domains ${ }^{4,19}$.

Only $51.8 \%$ of PLWHA interviewed herein were employed, despite the fact that $93.0 \%$ were of working age. Being unemployed was associated with low QoL in all domains, except spirituality. This result is similar to previous studies revealing that unemployment was associated with low QoL in all domains, except social relations and spirituality., ${ }^{4,6,18,20}$.

The individual income of the population studied was very low. More than half (56.3\%) of patients earned a maximum of one Brazilian minimum wage. Our findings are similar to those reported previously revealing that individuals without income or with an income lower than one minimum wage had low QoL scores in various domains ${ }^{21}$. Reis et al. $(2011)^{4}$ pointed out that higher income implies higher scores in all domains, except social relations. We found that low economic status was associated with low QoL in all domains. According to Passos ${ }^{9}$, belonging to a given socioeconomic level is a variable related to other factors such as income, level of education, and social support network, which might affect QoL.

Among patients interviewed, $90.4 \%$ had been diagnosed as HIV positive for two or more years before the start of the study. The percentage of patients receiving ART (89.8\%) was very close to the target set out by the United Nations Joint Program on HIV/AIDS and by the Brazilian government, which states that access to ART should reach at least $90 \%$ of PLHA $^{22}$. The intermediate level of QoL found in the studied population could be explained by the high proportion of patients under ART. This result is in accordance with Karkashadze et al. ${ }^{23}$ showing that PLWHA younger than 40 years had lower QoL whereas individuals under ART had higher QoL scores.

The mean survival time after diagnosis ( 8 years) indicated that the average survival of PLWHA in the north of Minas Gerais is close to the national survival mean before the introduction of highly active antiretroviral therapy (HAART), which was approximately 108 months ${ }^{24}$. Tancredi and Waldman ${ }^{25}$ showed that survival of people with AIDS in a cohort of HIV patients increased progressively after HAART adoption Viral load was undetectable (less than or equal to 50 copies $/ \mathrm{mm}^{3}$ ) in $65.0 \%$ of patients' tests. This percentage is below the target set out by UNAIDS ${ }^{25}$ stating that $90 \%$ of people receiving ART should have undetectable plasma viral load after six months of treatment. Nevertheless, patients studied had acceptable CD4 ${ }^{+}$ T-lymphocyte counts and their immune system was probably functioning adequately. In fact, only $7.1 \%$ had a count that was lower than 200 copies $/ \mathrm{mm}^{3}$. The mean $\mathrm{CD}^{+} \mathrm{T}$-lymphocyte count (594 cells $/ \mathrm{mm}^{3}$ ) was higher than that reported by Tancredi and Waldman for PLWHA under HAART ${ }^{25}$. In this study, the plasma viral load had no statistical association with the QoL of these patients.

$\mathrm{CD}^{+}$T-lymphocyte cell count below 500 cells $/ \mathrm{mm}^{3}$ negatively influenced the psychological domain. Medeiros and Saldanha ${ }^{26}$ found that patients with $\mathrm{CD} 4^{+} \mathrm{T}$-lymphocyte cell counts above 500 cells $/ \mathrm{mm} 3$ evaluated their lives better than patients with $\mathrm{CD}^{+}$T-lymphocyte cell counts below $500 \mathrm{~mm}^{3}$. Passos and Souza ${ }^{9}$ showed that patients with CD4 $4^{+}$T-lymphocyte cell count below 350 had worse scores in the physical and independence domains.

Clinical variables showed an association with few domains of QoL, which is interesting since other studies that have analyzed these type of variables did not find any associations at all ${ }^{8,9,18}$. In this study, the evaluation of the clinical variable depression revealed that $43.3 \%$ of patients were affected by depression. Among them, $21.2 \%$ had slight depression symptoms, while $11.7 \%$ and $10.4 \%$ had moderate and severe depression symptoms, respectively. This result is in agreement with findings reported by Malbergier and Schoffel ${ }^{27}$. We found

TABLE 5: Proportion of people living with HIVIAIDS with scores lower than the third tertile in each WHOQoL-HIV Bref domain showing depression symptoms. Montes Claros, MG, Brazil, 2014.

\begin{tabular}{|c|c|c|c|c|c|c|c|}
\hline Depression & Physical & Psychological & $\begin{array}{c}\text { Independence } \\
\text { level }\end{array}$ & $\begin{array}{c}\text { Social } \\
\text { relations }\end{array}$ & Environment & Spirituality & QoL-Overall \\
\hline $\begin{array}{l}\text { No symp- } \\
\text { toms }\end{array}$ & $23.5 \%$ & $12.0 \%$ & $24.7 \%$ & $26.3 \%$ & $30.7 \%$ & $30.9 \%$ & $34.0 \%$ \\
\hline $\begin{array}{l}\text { With symp- } \\
\text { toms }\end{array}$ & $76.5 \%$ & $88.0 \%$ & $75.3 \%$ & $73.8 \%$ & $69.3 \%$ & $69.1 \%$ & $66.0 \%$ \\
\hline
\end{tabular}


that the proportion of patients with depression in the lower tertiles relating to QoL was twice as high as those without depression, who were in the upper tertile in all domains (Table 5). The final model adopted shows an association between depression and low QoL in all domains, which corroborates findings from other studies conducted in Brazil2,4,9,28.

Depression is one of the most common psychiatric disorders among PLWHA ${ }^{13}$. The prevalence of depressive disorders in HIV infected patients varies from $12 \%$ to $66 \%$, and depressive disorders are undiagnosed in $50 \%$ to $60 \%$ of those patients ${ }^{29}$.

It is worth noting that the PLWHA analyzed in this study included recently diagnosed patients, and this may have hindered the cross-referencing of variables with the time of diagnosis. This cross-sectional study may be limited by the survival bias and the difficulty in establishing causal inferences.

Although PLWHA studied herein were poor and lived in an impoverished part of Brazil, $90 \%$ of them had free access to ART, provided by the public health system (SUS - Brazilian Health System) without extra costs for patients. We found that being female, under the age of 44, lower socioeconomic level, and $\mathrm{CD} 4^{+} \mathrm{T}$-lymphocyte $<500$ copies $/ \mathrm{mm}^{3}$ were associated with a lower QoL. Suffering from depression was one of the main predictors of low QoL. Therefore, it is important that care for PLHA include measures to improve their socioeconomic status and offering specialized attention to mental disorders aimed at reducing the impact of depression on these patients' QoL.

\section{Acknowledgments}

The authors would like to thank the Health Service Department of Montes Claros for helping with the logistics necessary to accomplish this research. We thank Unimontes (State University of Minas Gerais), the Graduate Program in Health Sciences - Infectology and Tropical Medicine of the Federal University of Minas Gerais, our co-workers, trainees, and the patients who collaborated to accomplish this study.

\section{Conflict of Interest}

The authors declare that there is no conflict of interest.

\section{REFERENCES}

1. Brazil, Ministry of Health. Boletim Epidemiológico - AIDS e DST. Ministério da Saúde - Secretaria de Vigilância em Saúde Departamento de DST, AIDS e Hepatites Virais. Brasília. 2014.

2. Souza-Jr PRB, Szwarcwald CL, Castilho EA. Delay in introducing antiretroviral therapy in patients infected by HIV in Brazil, 20032006. Clinics. 2007;62(5):579-84.

3. Razera F, Ferreira J, Bonamigo RR. Factors associated with healthrelated quality-of-life. Int J STD AIDS. 2008;19(8):519-23.

4. Reis RK, Santos CB dos, Dantas RAS, Gir E. Qualidade de vida, aspectos sociodemográficos e de sexualidade de pessoas vivendo com HIV/AIDS. Texto Contexto Enferm. 2011;20(3):565-75.

5. World Health Organization. The WHOQOL-HIV group. WHOQOL-HIV instrument: users manual. Geneva 2002.

6. Zimpel, R, Fleck, MP. Quality of life in HIV-positive Brazilians: application and validation of the WHOQOL-HIV, Brazilian version. AIDS Care. 2007;19(7):923-30.
7. Santos ECM dos, França Junior, Lopes F. Quality of life of people living with HIV/AIDS in São Paulo, Brazil. Rev Saúde Pública. 2007;41(Suppl 2):64-71.

8. Gaspar J, Reis RK, Pereira FMV, Neves LAS, Castrighini CC, Gir E. Quality of life in women with HIV/AIDS in a municipality in the state of São Paulo. Rev Esc Enferm USP. 2011;45(1):230-6.

9. Passos SMK, Souza LDM. An evaluation of quality of life and ists determinants among people living with HIV/AIDS from Southern Brazil. Cad Saúde Pública. 2015;31(4)800-14.

10. Arango HG. Bioestatística: Teórica e computacional. 2 ed. Rio de Janeiro: Guanabara Koogan, 2005.

11. Folstein MF, Folstein SE, McHugh PR. Mini-mental state. A practical method for grading the cognitive state of patients for the clinician. J Psychiatr Res. 1975;12(3):189-98.

12. Gomes-Oliveira MH, Gorenstein C, Lotufo Neto F, Andrade LH, Wang YP. Validation od the Brzilian Portuguese version of the Beck Depression Inventori-II in a community sample. Rev Bras Psiquiatr. 2012;34(4):389-94.

13. Paz Filho GJ, Sato LJ, Tuleski MJ, Takata SY, Ranzi CCC, Saruhashi SY, et al. Emprego do questionário CAGE para detecção de transtornos de uso de álcool em pronto-socorro. Rev Assoc Med Brasil. 2001;47(1):65-9.

14. ABEP (Associação Brasileira de Empresas de Pesquisa). Critério de Classificação Econômica Brasil. 2011. Available in: https://www.ebep.org. Access in 2014/03/02.

15. PNUD BRAZIL. Human Development and HDI. Available in: http:// www.br.undp.org/content/brazil/pt/home/, access in 2014/05/15.

16. Pereira M, Canavarro MC. Gender and age diferences in quality of life and the impacto of pysichopathological symptoms among HIVinfected patients. AIDS Behav. 2011;15(8):1857-69.

17. Gir E, Vaichulonis CG, Oliveira MD. Adesão à terapêutica antirretroviral por inidivíduos com HIV/AIDS assistidos em uma instituição do interior paulista. Rev Lat Am Enfermagem. 2005;13(5):634-41.

18. Ferreira BE, Oliveira IM, Paniago AMM. Quality of life of people living with HIV/AIDS and its relationship with CD4+ linphovytres, viral load and time of diagnosis. Rev Bras Epidemiol. 2012;15(1):7584.

19. Oliveira Filho JS, Silva PE, Freitas FFQ, Soares JP, Costa MAG, Silva ACO. Qualidade de vida de pessoas vivendo com HIV/AIDS. Revista Baiana de Enfermagem 2014;28(1):61-68.

20. Calvetti PU, Muller MC, Nunes MLT. Qualidade de vida e bemestar espiritual em pessoas vivendo com HIV/AIDS. Psicol Estud. 2008;13(3)523-39.

21. Remor EA. Aspectos Psicossociais na Era dos Novos Tratamentos da AIDS. Psicologia. Teoria e Pesquisa. Universidad Autónoma de Madri. 2002;18:283-287.

22. Karkashadze E, Gates MA, Chkhartishvilli N, DeHovitz J, Tsetsvadze, T. Assessment of quality of life in people living with HIV in Georgia. Int J STD AIDS. 2017;28(7):672-8.

23. Brasil, Ministry of Health. Boletim Epidemiológico - AIDS e DST. Ministério da Saúde - Secretaria de Vigilância em Saúde Departamento de DST, AIDS e Hepatites Virais. Brasília. 2010.

24. Tancredi MV, Waldman EA. Predictors of progression to AIDS after HIV infection diagnosis in the pre-and-post HAART eras in Brazilian AIDS-free cohort. Trans R Soc Trop Med Hyg. 2014;108(7):408-14. 
25. UNAIDS. Ambitious treatment tagets: writing the final chapter of the Aids epidemic. 2014. Available in: http://www.unaids.org/sites/ default/files/media_asset/JC2670_UNAIDS_Treatment_Targets en.pdf. Access in: 12/04/2015.

26. Medeiros B, Saldanha AAW. Religiosidade e qualidade de vida em pessoas vivendo com HIV/Aids. Estudos de Psicologia. 2012;29(1):53-61.

27. Malbergier A, Schoffel AC. Tratamento de depressão em indivíduos infectados pelo HIV. Rev Bras Psiquiatr. 2001;23(3):160-7.
28. Souza Junior PRB, Szwarcwald CL, Castilho EA. Self-rated health by HIV-infected individuals undergoing antiretroviral therapy in Brazil. Cad Saúde Pública. 2011;27(Supp 1):S56-66.

29. Silveira, MPT, Guttier MC, Pinheiro CAT. Depressive symptoms in HIV-infected patients treated with highly active antiretroviral therapy. Rev Bras Psiquiatr. 2012;34(2):162-7. 